\section{Uneasy listening: El subutilizado arte de sonificar datos para contar historias de injusticias sociales}

UNEASY LISTENING: THE UNDERUSED ART OF SONIFYING DATA

TO TELL STORIES OF SOCIAL INJUSTICES
2012
En este artículo exploramos el uso de la sonificación de datos a través de emplos y entrevistas a personas que han desarrollado proyectos que abarcan una amplia gama de temas, desde la cultura hasta el activismo de derechos humanos, entre los que destaca Egypt Building Collapses, una visualización y sonificación dirigida por Tactical Tech en colaboración con Yahia Shawkat y la Iniciativa Egipcia por los Derechos Personales. Además, presentamos los tres tipos de información que resultan más adecuados para ser transformados en sonido audible. Junto a ello, planteamos una interrogante acerca de los medios tradicionalmente utilizados por activistas, quienes por lo general tienden a la visualización. El artículo no pretende formular una crítica contra lo visual, sino elaborar un argumento a favor del sugerente territorio de lo auditivo, cuyo potencial permanece en gran medida inexplorado.

Tactical Tech, el colectivo en el que participamos, es una ONG basada en Berlín, en la que trabajan expertos en tecnologías, activistas, diseñadores y profesionales, quienes colaboran con ciudadanos, periodistas y líderes para crear conciencia acerca de la información personal, la privacidad y la seguridad digital.

In this article, we explore the use of data sonification through examples and interviews with people that have developed projects that span a wide variety of subjects, from culture to human rights activism, among which stands out Egypt Building Collapses, a visualization and sonification conducted by Tactical Tech in collaboration with Yahia Shawkat and the Egyptian Initiative for Personal Rights. We also present here three types of information that are adequate to transform into audible sound. Along this, we pose the question about the media traditionally used by activists, who generally tend to favour visualizations. The article does not pretend to formulate a critique of the visual, but rather elaborate an argument in favour of the compelling territory of sound, whose potential remains largely unexplored.

Tactical Tech, the collective in which we participate, is a NGO based in Berlin in which expert in technologies, activists, journalists and leaders work to create awareness about personal information, privacy and digital security.
GABI SOBLIYE Berlin, Germany
gabietacticattech.or

LEIL-ZAHRA MORTADA

Berlin, Germany
leiletacticaltech.org

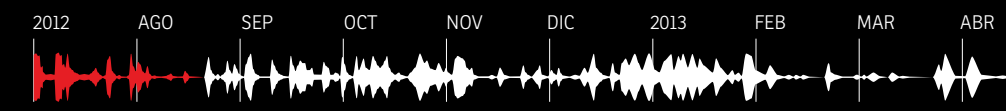


Hay un hecho innegable: el arte ce transformar datos en sonido, subutilizado tanto para narrar historias de abusos a los derechos humanos como para hacer visibles las injus sociales. Considerando la base de 政 cacción y el proposito previsto en conciencia de un to qué Pantear una interrogante en relación a a decisión de utilizar lo visual en forma exclusiva y por defecto. Sobre todo porque a la información también se le puede dar salida en un formato auditivo.

«Todos los manifestantes $y$ activistas recogen información que luego utilizan estratégicamente para influir en la política y el debate público, para exponer malas prácticas, presionar por justicia, vigitar a quienes instituciones públicas Nurestro uso efectivo de la información, así como la manera en que la presentamos, depende de nuestra capacidad para comunicarla exitosamente. (...) Un buen diseño para visualizar información en campañas es el que logra los culturales, sociares y políticas. Al usar información visual en campañas debemos considerar su base de interacción, que a grandes rasgos corresponde a la red de personas que de diversas maneras están involucradas en el asunto» Tactical Technology Collective,

Sorprendentemente, el sonido ha sido poco explorado como medio y muchas veces ni siquiera se $l o$ búsqueda rápida del término "data sonification" en Google produce tan solo 253.000 resultados; en cambio la búsqueda de "data visualization" produce casi 9 millones. Aun asi, estamos rodeados de ejemplos que demuestran que el sonido es óptim para comunicar información, inclus
There is an undeniable fact: the known as 'data sonifacationt' sound, underused to tell stories about abuses human rights as well as to make social injustices visible. Considering the base of interaction and the intended purpose in aware of a dist ar to make people the guestion around the exclusive and default choice of using the visual. Abov all, because data can also be represented into an auditory outcome.

"All advocates and campaigners collect information that they can then use strategically to influence policy and public debate, expose wrong-doing, push for justice, monitor those in power and regulate public institutions. Our effective use and presentation of to communicate it successfully. to communicate it successfuly. information for advocacy is one that achieves its intended purpose
within a network of cultural, social and political interactions. In using visual information for advocacy, we have to consider its base of interaction, broadly meaning, the with the issue in different ways" (Tactical Technology Collective, 2014, pp. 10-14).

Surprisingly, sound has been little explored as medium, and often not in as antion. A quick os up 253,000 search resultsi alternatively, searching for 'data visualization' produces nearly 9 million results. It is surprising to see how little or even considered as an option. vetwe are surrounded by examples communicating information, even on a daily basis.
Desde una alerta telefónica al aviso de un nuevo e-mail, o desde una que pasa, muchas señales pueden ser consideradas como interpretaciones La sorpresa frente at hecho de que las visualizaciones tengan más preponderancia que tas sonificacion radica en el siguiente factor: el capturar nuestra capaciad de visual, ya que el sonido entrega una experiencia corporal que no compromete únicamente a nuestros oídos. Ocurre que La reacción frente a sonido, a cualquier sonido, involucra una respuesta fisiologica mucho $\mathrm{ma}$ ta imagen. En conse la que genera la imagen. En consecuencia, nuestros formas ibran con el sonido de organismo cuando está expuesto a estímulos visuales.

Las vibraciones lumínicas pasa fácilmente a través del medio transmisor (aire, agua, cristal, etc) sin cambiar o perturbar el medio, hasta que son recibidas por el jo. En lo esencial, ellas no tienen efecto alguno en el cuerpo, excep a través de las reacciones que provocan dentro del ojo mismo, las que subsecuentemente product

(cansancio ocular, etc.). No es lo que ocurre con las vibraciones sonoras. Para que las vibraciones sonoras sean transmitidas, todo el medio transmisor (el aire o cualquier otro elemento conductor del sonido) tiene que vibrar de acuerdo a los patrones de la fuente de sonido, $y$ patrones de manera medible. Para oír los sonidos solamente, bastrí que el mecanismo auditivo dentro del oído vibrase en los patrones del sonido; pero para distinguir detalles y contenido expresivo (inflexiones de la voz, emociones, etc.), todo el cuerpo debe vibrar en dichos patrones con aquellos en el tiempoly (The Anstendig Institute, 1983).
From a phone alert to a new email, from fire alarm to an ambulance driving by. All of this can be seen as basic visualizations have preponderance over sonifications is based on the following fact: sound has a greater capacity to capture our attention than the visual, since sound delivers a corporal experien hat doest afects only our ears. As it response that is much deeper and multi layered than that of an image. Consequently, our bodies vibrate with sound in ways that are beyond our organ to visual stimuli. "Light vibrations pass easily
through the transmitting medium (air, water, glass, etc.) without changing or disturbing that mediu and are then taken in by the eye. They essentially have no effect reactions bithin the through the reactions within the eye itself that
subsequently cause reactions in the body (eyestrain, etc.). Not so with vibrations to be transmitted, the whole transmitting medium (the air or any other sound-conducting element) has to vibrate in the

patterns of the sound-source and the body has to measurably vibra the sounds, it would be enough for just the hearing mechanism with the ear to vibrate in the soun patterns, but to hear nuances and expressive content (voice inflections, emotions, etc.), the whole body has to vibrate in the patterns of those nuances

(The Anstendig Institute, 1983).

Nuestro uso efectivo de

la información, así como

La manera en que La presentamos, depende de nuestra capacidad para comunicarla exitosamente. (... Our effective use and presentation of information depends on our ability to communicate it successfully. pite this, at least since the Renaissance, the techniques for analysing the visual (Ihde, 2007, 2009). While ther are early examples of attempts to use sound as a primary means of monitoring recent approach to rendering information sensible and has been promoted 2011). A good example on that would be the use of sound in hospitals as an aid to the visual with the monitoring of vital signs, an example worth also looking at great resour dor resss sonification as a Just to pre are interested in here is not and possibly, in criftation as a valid efficient option than the visua we are also interested in posing the question around the mediums classically used for advocacy and activism around socia justice and human rights. A creative outline of possibil ristration and yield public response.

\section{SONIC STORYTELLING}

"The relationship to sensation central to sonification is most
distinctively characterized by the ability to transform data destined for one sense into data destined for another" (Sterne \& Akiyama, 2011,

Though translating data into sound is most commonly referred to as sonification, it can also be central a la sonificación nformación destinada a un sentido, (Sterne \& Akiyama, 2011, pág. 545).

Si bien comúnmente se conoce como "sonificación" a la actividad de trad usan los conceptos "display auditivo" "Infografía acústica". Jonathan Sterne yitchell Akiyama definen el término "soncacion" como ila transformación

(n) the "transformation of non-sonic data into audible sound" (Sterne \& Akiyama 2011, p. 545). what we are in rested hor hor 
Pero no toda la información del mismo mado que no todicada, nformación es adecuada para ser visualizada. A partir de nuestras investigaciones, podemos afirma que existen tres tipos de información Gueritun primer tipo corren sond aun que requiere que el público sea capaz de detectar patrones o interpretar pequeños cambios en el tiempo. gundo tipo es la información en vivo, particularmente aquella que está cambiando en tiempo real. El tercero gira en torno a los atributos etrá dispos que poseen los datosy puede ser transferida por medio de experiencia sónica.

Tanto para las unas como para las tras, uno de los principales desafís dice relación con el tipo de formato en el cual se difunden las sonificaciones, dado que solo pueden ser escuchadas en tínea o en espacios públicos (y no en formatos impresos). Esto limita considerablemente las posibilidades de drusion. Además, como no hay una

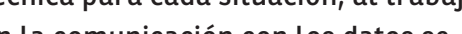
stá involucrada.

TIPOS DE INFORMACIÓN QUE SE PRESTAN PARA LA SONIFICACIÓN PATRONES Y CAMBIOS EN EL TIEMPO Il diablo está en los detalles

Tal como se mencionó

anteriormente, el sonido produce una amplia gama de alteraciones a nuestro alrededory dentro de nosotros para están capacitados para entender el sonido de forma innata y con más profundidad en comparación con la forma en que nuestros ojos comprenden las imágenes.

Por ejemplo, una sonificación do público por su aprovechamiento de los patrones es la pieza del New York Times titulada Fractions of $a$

Second: An Olympic Musical'. Si bien
But not all data is suitable to be Bified, Just as not all data is suitable can point three main oryes research, we are leaned on most often to be sonified. The first type is data that relies on the audience being able to spot patterns or second type is live data partic which is changing in reat particularly that centres around emotional attributes that data holds, and which is available wh an emotion can be best transferred through a sonic experience.

For all these types, one of the main challenges relates to the type of format in which sonifications are disseminated as they can only be heard online or in public spaces frather han in printed dissemination cansidrably the dissem nation capabilites. Besides, situation, when communicating with data one must consider what type of information is involved.

TYPES OF DATA THAT LEND

THEMSELVES TO SONIFICATION

PATTERNS AND CHANGES IN TIME

The devil is in the detail

As mentioned before, sound yields a wider range of atterations around and within us for us to hear it. Our bodies the meaning behind it in more depth compared to the way in which our eyes understand images.

For example, a sonification that has been particularly 'visible' to the public ear for its use of patterns is The New. York Times piece entitled Fractions of Second: An Olympic Musical'. Although it is not a piece that speaks about socia social o derechos humanos, vale ta transmitir un mensaje claro a partir del sonido. Fractions of a Second fue creada en 2010 por Amanda Cox, quien optó por una sonificación como la mejor manera de dar a entender que «un pestanie medalista que gana el oro de aque

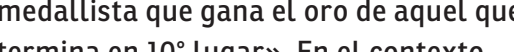

de esta minúscula diferencia, visión

imágenes fueron fácilmente superadas por el uso del sonido.

En el contexto de la reciente serie podcasts sobre el tema de las de Enrico Bertini y Moritz Stefaner, el cientifico Scott Hughes afirma lo siguien

«Realmente ayuda a ilustrar que el sonido se relaciona con una parte del cerebro muy distinta de la que está relacionada con las magenes. Crando lo escuchas,

visceral de lo cerca que llegan a

la meta estas mujeres. Esto me remonta a lo que un estudiante de posgrado en neurociencias me contó hace unos veintitantos años, la idea de que tenemos un maravilloso filtro para reconocer patrones, es increible como nuestro oido discrimina estas cosas de nuestro cerebro puede reconocer

patrones muy claramente. Esto le da una dimensión completamente distinta» (Hughes, 2016).

\section{Datos contrastantes}

Brian Foo, un artista y programador entrevistado para este artículo, destaca lo pegajosa que es la música que usa también conocido como Data-Driven $D J^{2}$, ha creado información musical sobre diversos temas, incluyendo la calidad del aire, el cambio climático y el movimiento global de refugiados. de visualización de datos en el Museo Americano de Historia Natural, donde comunica información climática a través de exposiciones digitales y físicas interactivas (Foo, s. a.a). A través de inequality or human rights, it is worth analysing for its capacity to convey a using sound. Fraction of a Second was created in 2010 by Amanda Cox, who chose a sonification as the best way to suggest that "a blink of an eye can be all that separates the gold medallist from the $10^{\text {th }}$ place finisher" difference, sight and visuals were easil outweighed by sound.

seres 'Data Stories' by Enent podcast and Moritz Stefaner on the subject of sonifications, the scientist Scott Hughes said this about Fractions of a Second:

"This really helps to illustrate the way in which sound just engages such a different part of your brain than pictures might. You really get
a visceral sense of how close some a visceral sense of how close some
of these things finish when you do it of these things finish when you do it
like that. It traces back to what that like that. It traces back to what that
neuroscience graduate student told me twenty some years ago, this idea for picking out patterns, that your ear is wonderful at discriminating these things very precisely and then your brain can pick up these patterns really clearly. This gives a whole other dimension to it (Hughes, 2016).

\section{Contrasting data}

Brian Foo, an artist and programmer interviewed for this article, highlighted the stickiness of music that he focuses on when creating sonic experiences. H is also known as the Data-Driven D ${ }^{2}$ subjects including air quation tatar and attraction and the global refuge movement. He recently became data visualization artist at the American Museum of Natural History, where he communicates weather information through digital and physical interactive

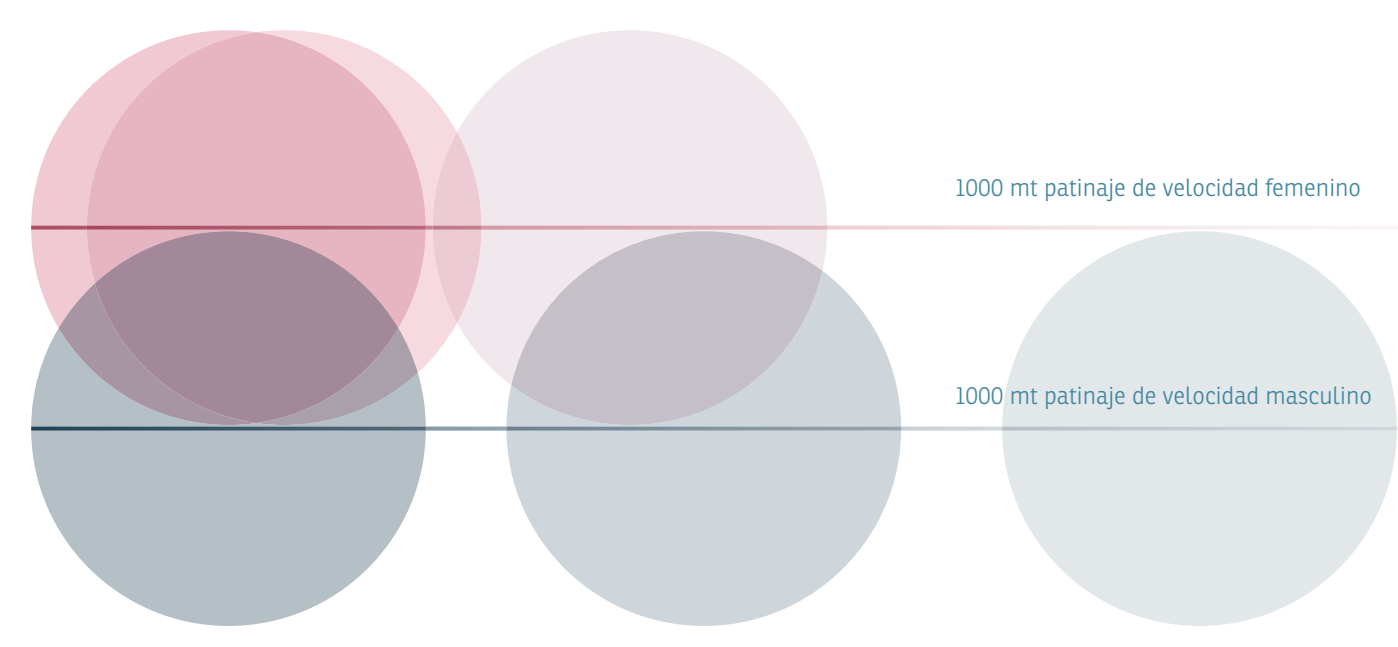

Reinterpretación gräffca de "Fractions of a Second: An Olympic Musical", deAmanda Cox (New York Times,

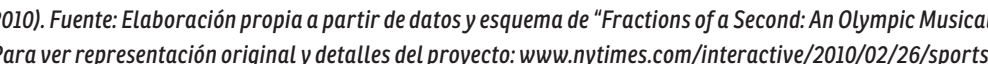
Ilympics/20100226-olysymphony.html?_r=16

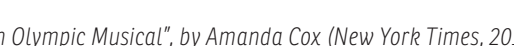

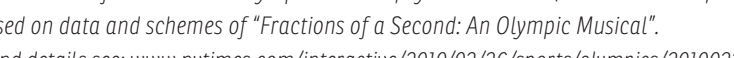

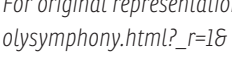

Fractions of a Second fue creada en 2010 por Amanda Cox

quien optó por una sonificación como la mejor manera de dar a

entender que «un pestañeo puede ser todo lo que separa al

medallista que gana el oro de aquel que termina en $10^{\circ}$ lugar».

Fractions of a Second was created in 2010 by Amanda Cox, who

chose a sonification as the best way to suggest that "a blink of an eye can be all

that separates the gold medallist from the $10^{\text {th }}$ place finisher". 
una serie de experimentos musicales, Foo combina datos, algoritmos y sonidos bjetivo de «explorar nuevas experien aprovechando la naturaleza temporal la música y su capacidad de alterar los

Respondiendo a una pregunta sobre apropiados para ser sonificados, Foo destacó que «los conjuntos de datos que contienen picos con puntos altos bajos de información son generalment los más apropiados» (comunicació

personal, 27 de febrero, 2017).

No obstante, puede ser interesante sonificar aquellos conjuntos de datos que resultan más bien monótonos, especialmente si el mensaje a transm es precisamente que la información tajó por era representación de etnicidad y género en las películas de Hollywood, en la que manejó información con muchos puntos de datos similares, que en este caso correspondian a hombres Lancos. El objetivo de esta canción más monótona, es que la experiencia se falta co representación producciones de Hollywood.

Datos en una serie tempora

El proyecto Egypt Building Collap

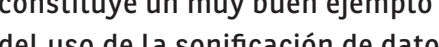

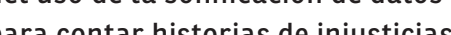
sociales. Dicho proyecto surge de circunstancia dramática ignorada dentro y fuera de Egipto: se estima solo entre 2012 y 2103, unos pocos años después de la Revolución Egipcia, al menos 192 personas murieron cuando más de 800 hogares se derrumbaron ausencia de control gubernamental sobre el entorno construido

(egyptbuildingcollapses.org, s, a.).

En un intento de hacer visible esta situación, en 2013 Tactical Tech estableció una colaboración con Yahia Shawkat y la Iniciativa Egipcia por los Derechos Personales. El objetivo xhibitions (Foo, n.d.a). Through a ries of musical experiments, de 10 Tooba - una organización que trabaja en justicia socialy elón que construido-, $y$ fundador de Shadow Ministry of Housing, un blog que critica la política de construcción en Egipto. La información no soloversaba sobre capacity to a ter ont's moral nature and When asking him about datasets more suitable than others to sonify, he highlighted that "datasets that contain "often more sutabte to sonify" (personat communication, February 27,2017 ). However, datasets that are more monotonous or flat can be interesting sonify, especially if the message of the data is to transmit that the data is flat. For example, Foo also worked on a pie looking at the representation of ethnicily and gender in Hollywood films, in which he processed information containing a lot of similar data points, which in this case corresponded to white males. The being that the experience should feel precisely to highlight the lack of ethnica representation in Hollywood producto

\section{ime-series data}

The project Egypt Building Collapses s a very good example of the use of injustices. This project emerges from a dramatic situation that has been overlooked in and outside of Egypt: it is
estimated that only between 2012 and 2013 , just a few years after the Egyp Revolution, at least 192 persons died whe more than 800 homes collapsed due to bad planning and absence of govern
control over the built environment (egyptbuildingcollapses.org, n.d.).

In an attempt to make this situation visible, in 2013 Tactical Tech established Egyptian Initiative for Personal Rights. el fatal colapso repentino de casas

sobre las razones que explican esta tragedia. Los datos recogidos incluye el número de muertos y heridos, así como el total estimado de personas que quedaron sin hogar, además del lugar en que se produjeron los derrumbes. Las causas que explicarían el colapso de estas viviendas van desd por parte de buscadores de tesoros de las nuevas edificaciones, pasando cumplen los estándares de seguridad supuestamente exigidos. La información en esta visualización cubre un año completo, desde julio de 2012 hasta junio de 2013, un período en el que no (egyptbuildingcollapses.org, s. a.).

A través de un trabajo conjunto, A traves de unief que identifica, preparamos un brief que identificaba de representación, los tabúes y los antecedentes. Queríamos comunicarnos media, políticamente despierto, que posiblemente desconocía la causa de la perdida de vidas y hogares. Éramos capacidad de con tanta facilidad como puede ayudar a dar a entender la magnitud de un problema, de modo que tuvimos el cuidado de trabajar con un diseñador de sonido que preparó varias muestras grupos de oyentes.

Decidimos crear una sonificación utilizando una de las categorías recogidas. el tiempo. Descubrimos que nos enfrentábamos a un problema de escala. Comprimimos el período de año en una pieza de 2,35 minutos, de modo que cada incidente se reflejara en esa línea de tiempo. Hoy pensamos
que, considerando los breves lapsos d por parte de buscadores de tesoros por el uso de cañerías de gas que no inundaciones repentinas o tes como con un público egipcio de clase que sometimos a prueba con diversos
The aim was to represent a dataset collected by Shawkat, co-founder of 10 Tooba - an organisation environment - and founder of Shadow Ministry of Housing - a blog that criticizes building policies in Egypt. The information not only dealt with the deadly sudden collapses of houses and building in Egypt, but also with the reasons that explain this tragedy. The of people dead and injured, as well as the total estimate of people that were left homeless and the places where the collapses occurred. The causes that explain the collapse of these homes range from the existence of illegal digging by treasure hunters to the poor construction quality of new buildings, to the use of gas pipetines supposedly mandated. The data in this visualisation covers a full year, from July 2012 until June 2013, a year that did not see large natural disasters such as flash floods or earthquakes

(egyptbuildingcollapses.org, n.d.).

Through working together, we prepared a brief that identified the audience, messaging, the format of the representation, taboos and examples communicate the loss of lives and homes and to try to connect with a middle-class, politically-aware Egyptian audience We were aware that sound has the capacity to annoy and intrude as easily as it can aid understand the magnitude of the problem, so we were careful to work with a sound-designer that prepared various samples of the sound for which we tes out the impact hey had on viewers. We decided to create a sonification ime. We learned that through using the as the focus point we faced a problem of scale. We compressed the one year period into a 2.35 minutes piece so each incident was reflected on this timeline. Today we believe that, considering the

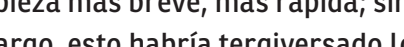
datos, ya que para acortar la pieza habriamos tenido que reducir de esca cosinges lo que habria hecho que chan de esta pieza más adelante.

ESCUCHANDO DATOS EN TIEMPO REA Dentro de la sonificación existe un subgrupo enfocado exclusivamente en sonificar eventos o instancias qu manera el jemplo más bésierta

tipo de sonificación son los sonidos de una unidad de cuidados intensivos de hospital (se trata de una herramienta que ayuda al equipo médico a atender diversas tareas sin tener que permanecer fijo frente a un monitor Visual, porque, como dice la pionera de la música electronica Pauline Oliveros, Un proyecto emblemático de real es Bittisten ${ }^{4}$, un trabajo de Maximillist un trabajo de transacciones de Bitcoins. Inspirados en dicho proyecto, durante los últimos años, Stephen LaPorte y Mahmoud Hashemi han estado desarrollando y manteniendo Listen to Wikipedia ${ }^{5}$, ana sonion ediones de la popular enciclopeda ofrecer a los us a is una nueva manera de relacionarse con Wikipedia, un sitio web principalmente basado en del mundo, la misión de Wikipedia es aer a ta mayor cantidad posible de usuarios y ofrecer múltiples niveles de entrada para que la gente contribuya 4 obtenga información del sitio. Los dos una nueva perspectiva, permitiendo una nueva perspectiva, permitien la información existente, pero de una manera diferente. Un objetivo secundario que ambos compartían era motivar a más personas a escribir artículos en Wikipedia, para lo cual resultaba importante comprender proceso mediante el cual son creados los artículos. short online attention spans, we would have created a shorter, faster piece; the data, since to shorten the piece we would have had to scale down the incidents, which would have made them ar fully. We'll refer to th piece later.

LISTENING IN REAL TIME

There is a sub-set within sonification focused entirely on sonifying events or instances occurring in real time. In a way, the most basic example of this type in a hospital's intensive care unit lit's tool that allows the medical team to attend to various tasks without having o stay pinned to a visual monitor, for, as pioneer Pauline Oliveros says, we cannot turn off our ears).

is BitListen" sifiative by Maximillian Laumeister that sonifies Bitcoin transactions. Inspired in this project, during the last few Hashemi have been developing and maintaining Listen to Wibipedias a real-time sonification of the edits of the popular online encyclopaedia. LaPorte and Hashemi wanted to offer users a new way of engaging with Wikipedia, a mainly ext-based website. As the world's largest atract as many Wikipedia mission is to offer multiple entry levers for peop cer multiple entry levels for people to website The two developers set out to create a new perspective, enabling users to relate to the data that already exists but in a new way. A secondary goal they shared was to encourage more people to contribute to Wikipedia through writing articles, for which it was important to articles are created.

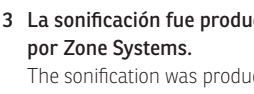


1985

$1000+$ refugees: 38

1995

World Population: 5,714,716,950

World Refugees: $12,682,853$ ( 1 in 450 )

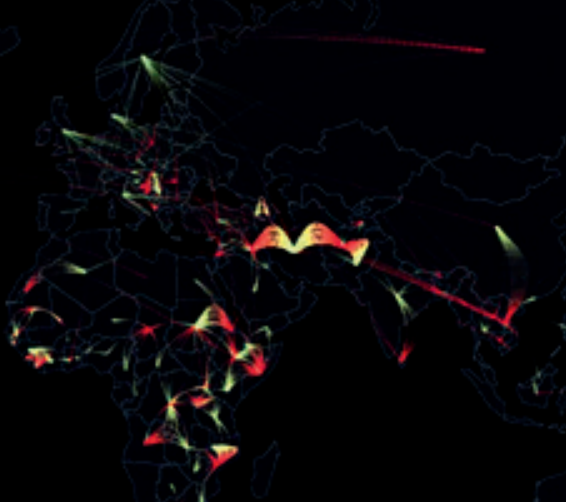

2003

World Population: 6,349,177,990

World Refugees: $9,238,044$ ( 1 in 687
Countries with $1000+$ refugees: 86
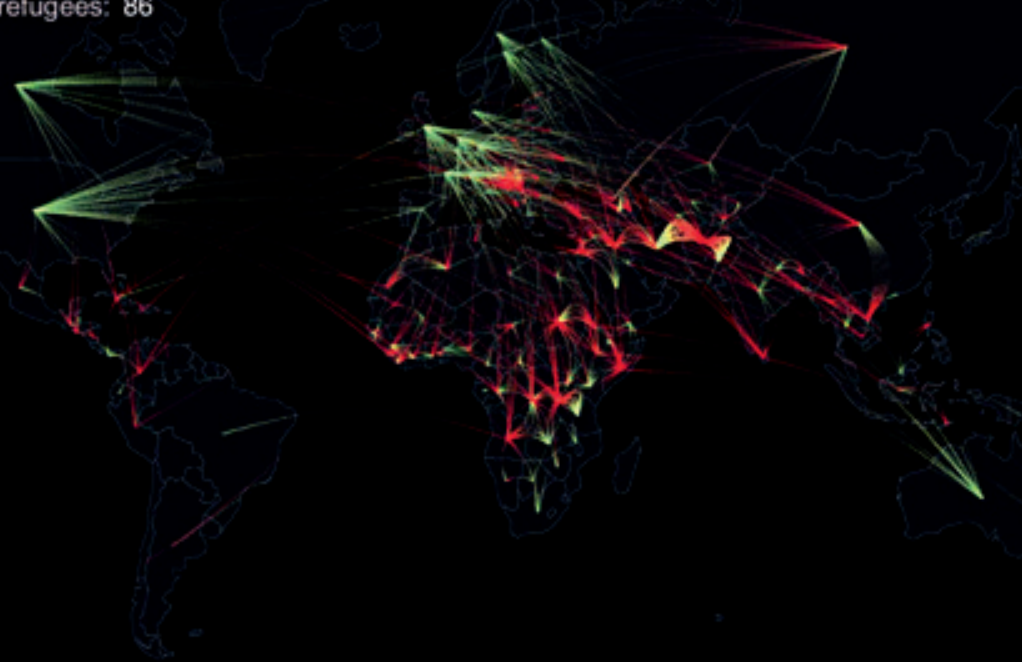

2006

World Refugees: $9,598,000$ ( 1 in 685$)$
Countries with $1000+$ refugees: 92

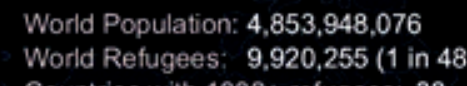

1990

World Population: $5,296,211,383$

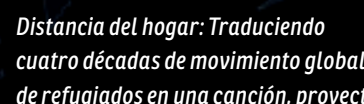

de refugiados en una cancicion, provecto
creado por Brian Foo en enero de

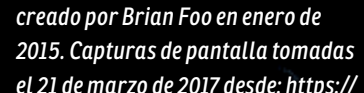

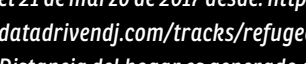

Distancia del hogare res generadoc
partirid dedatos recolectados or

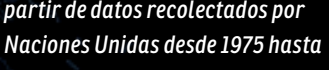

2012 acerca del movimiento global
derefugiados. La cantidad, longitudy

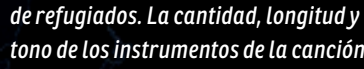

estan controladdos por el volumen

demovimimento de los refupigiadossy la

origeny usilo. Caddañoes representron

por cuatros segundos.

1998

World Population: $5,958,950,337$
World Refugees: $10,381,406(1$ in 574
Countries with $1000+$ refugees: 80
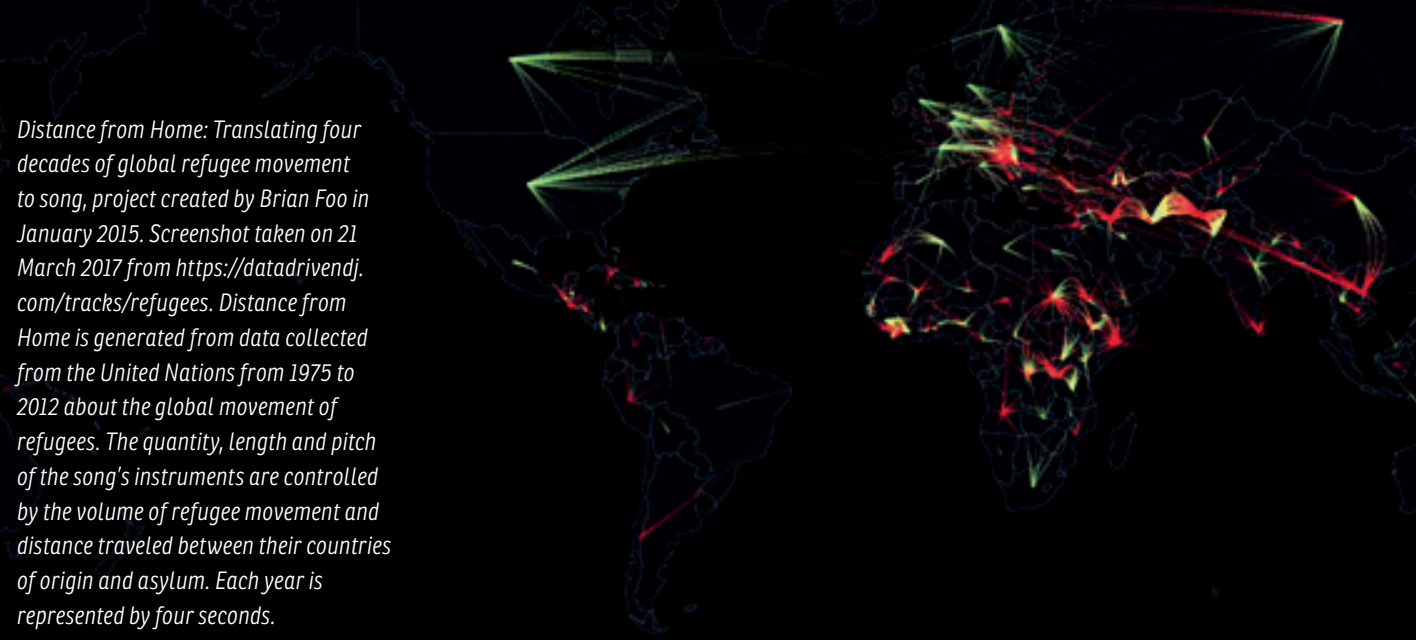

World Population: 6,580,545,179
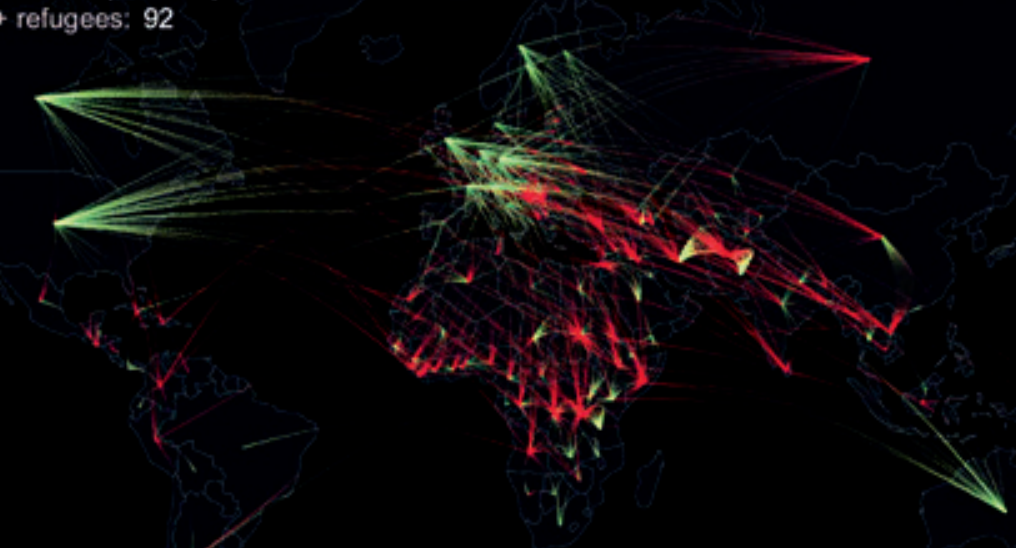

2012

World Population: $7,082,246,845$
World Refugees: $10,352,856(1$ in 685$)$
Countries with $1000+$ refugees: 97
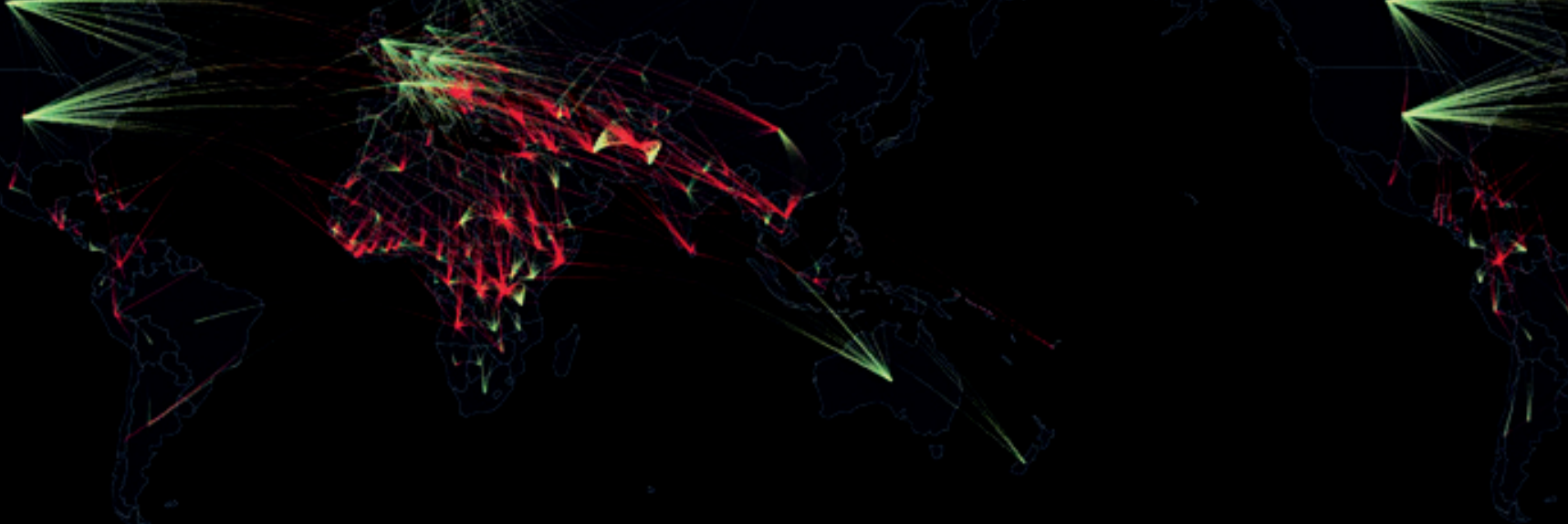

Country of Origin
Country of Asylum 

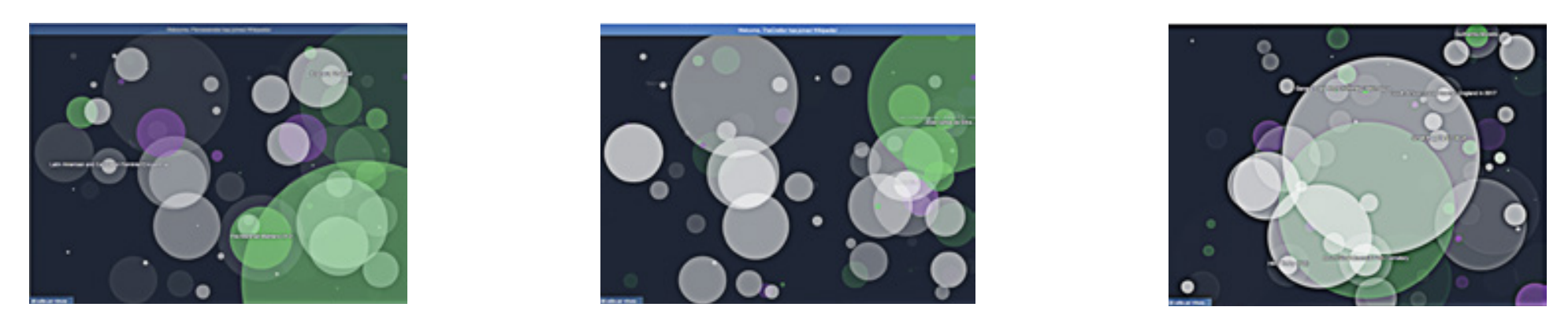

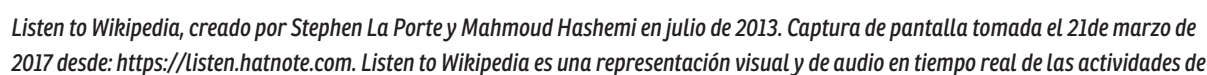

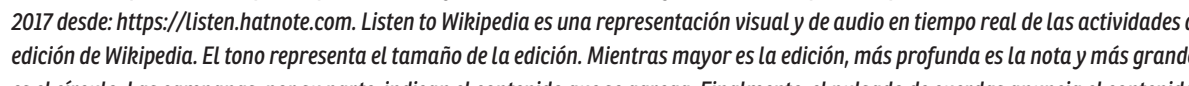

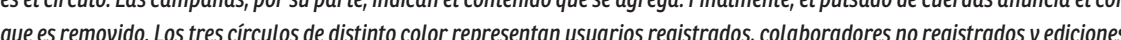

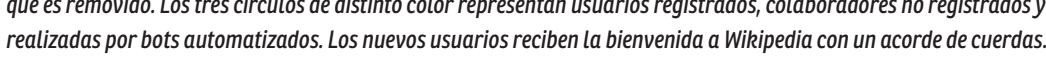
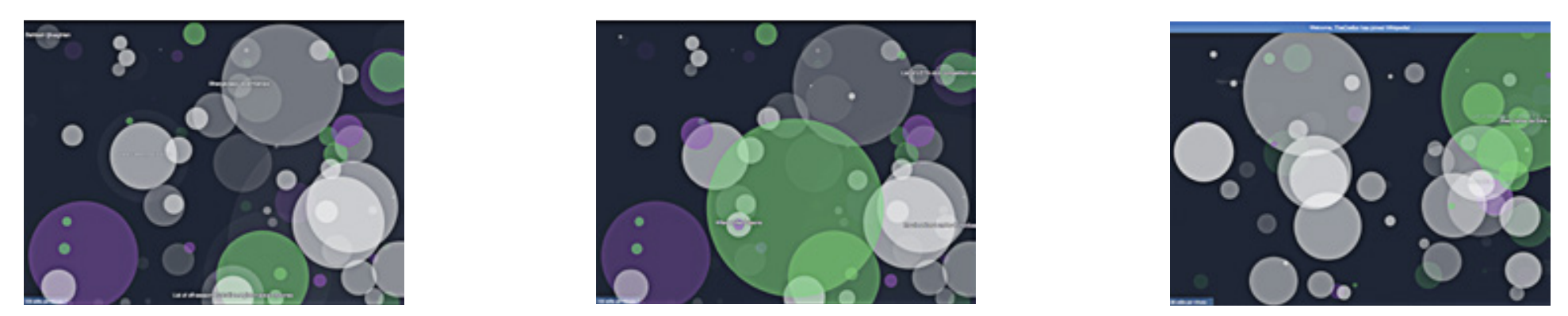

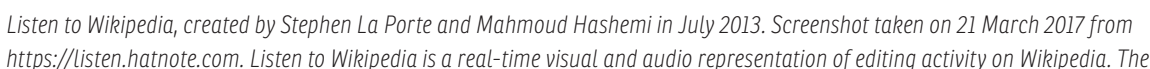

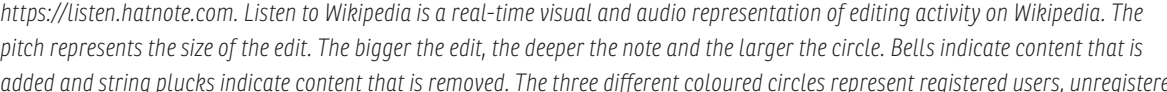

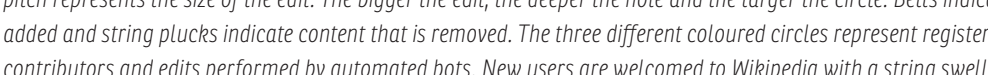
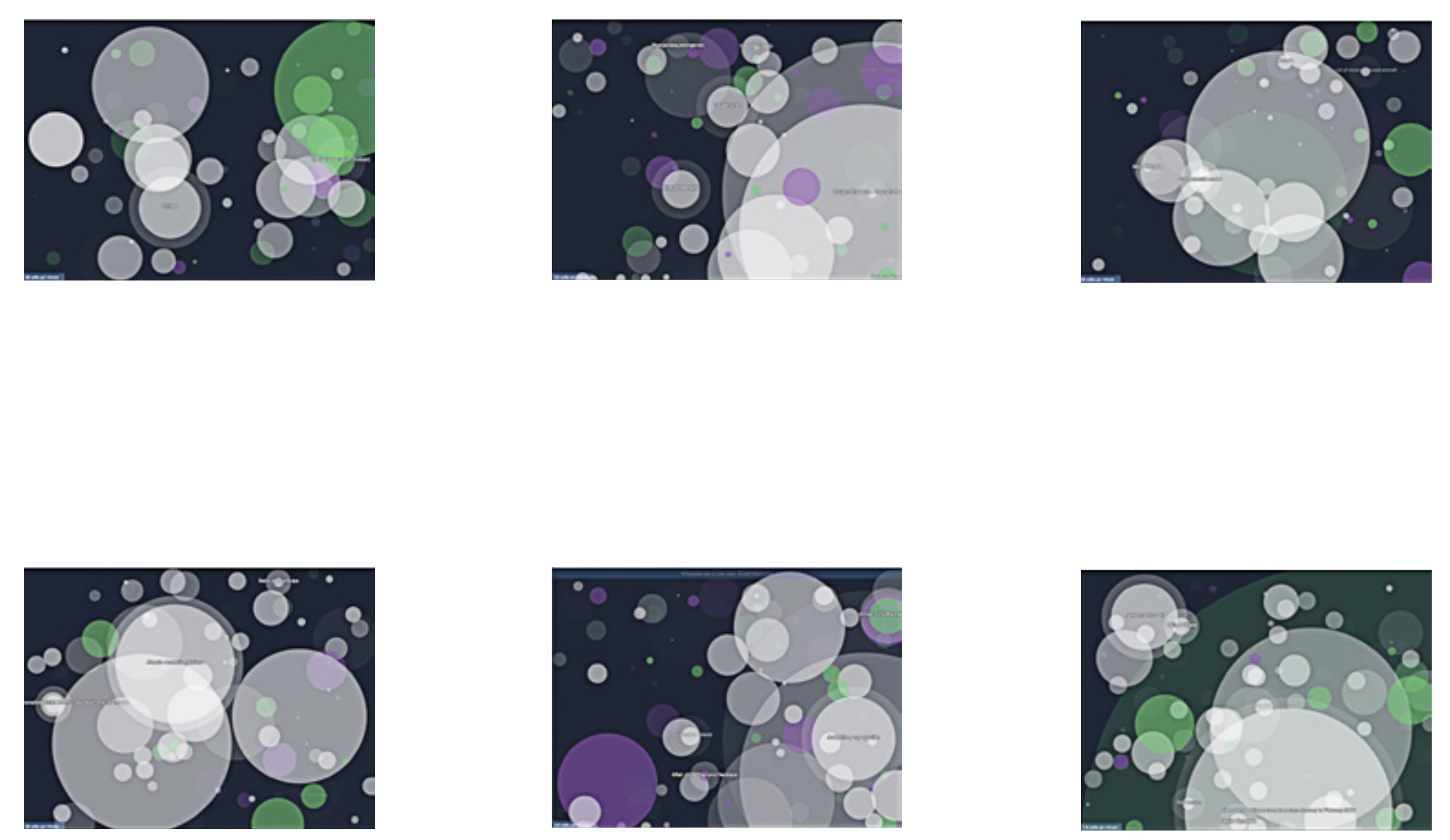

Wikipedia puede parecer un poco estatica, pero como explican los autores que está cambiando muchas veces a cada minuto. «Queríamos crear una sensaciôn de comunidad entre los editores. Me gusta imaginar que algu que esta escristendo un articlo, lo que te sesten to Wihipa sollaria, une a otros que escriben artículos. Es como una sinfonía distribuida» (S. LaPorte \& M. Hashemi, comunicación personal, 16 de febrero, 2017).

Tal como afirman LaPorte y Hashemi: «Dado que [el proyecto] es cautivador, puedes sentarte y en segundo plano, escuchando a la Wikipedia árabe despertar con un estallido de actividad de edición. Y esto no ocurriría con un mapa» (comunicación personal, 16 de

ATRIBUTOS EMOCIONALES DE LOS DATOS El sonido es un sentimiento capacidad de inducir sentimientos relevantes, sobre todo si se trata de

representar datos para contar historias de injusticias sociales. Nos referimos a la empatía, la compasión ola preocupacion, emocionales. Tal como mencion

a

crear sonificaciones pegajoss mientras respeta, al mismo tiempo, el carácter de la información en términos de precisión y temática (comunicación personal, 16 de febrero, 2017).

Foo identifica dos tipos de sonidos para sonificaciones: datos que suenan como datos y música que la gente escucharía basada en datos (comunicación persona 16 de rebro, 2017). A traves de su

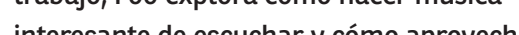
las cosas que la música sabe hacer bien para comunicar información acerca de una causa determinada. Todo ello está bien interpretado en una de sus sonificaciones,

que representa el movimiento global de refugiados en las últimas cuatro décadas.

En consecuencia, crear una sonificación para las el sonido de hombres escribiendo acerca de cultura, historia, cultura popular y ciencia. Consequently, to create a sonification of Wikipedia edits also amounts to creating the sound of men writing about culture, history, popular culture and science. ediciones de Wikipedia equivale también a crear

Wikipedia can feel a little static, but as the authors of Listen to Wikipedia mes a minute. "We wanted to create the to imagine somebody writting an and turn on Listen to whipediut oined by others writing articles, it's like distributed symphony" (S. LaPorte $\&$ .

LaPorte and Hashemi point out: "Since (the project) is it was watch it for a while or keep it in

the background, hearing Arabic Wikipedia waking up with a burst of not in your time zone. And this would comapen with a map" (Personal

EMOTIONAL AT TRIBUTES OF DATA Sound is a feeling

Like music, sound has the ability to induce relevant feelings, especially if the aim is to represent data to tell referring to empathy, compassion or concern, among other emotional Brian Foo strives to mentioned earlier, that are catchy while in the same

accuracy and subject matter (personal communication, February 27, 2017). Foo identifies two types of sounds for sonifications: data that sounds like that people would listen to (personal communication, February 27, 2017). Ins work, Foo explores how one can a hat music does wello on things Information around a certain cause. of this is exemplified in one of his sonifications, which looks at the movement refugees over the last two decades. a community feeling with the editors. 


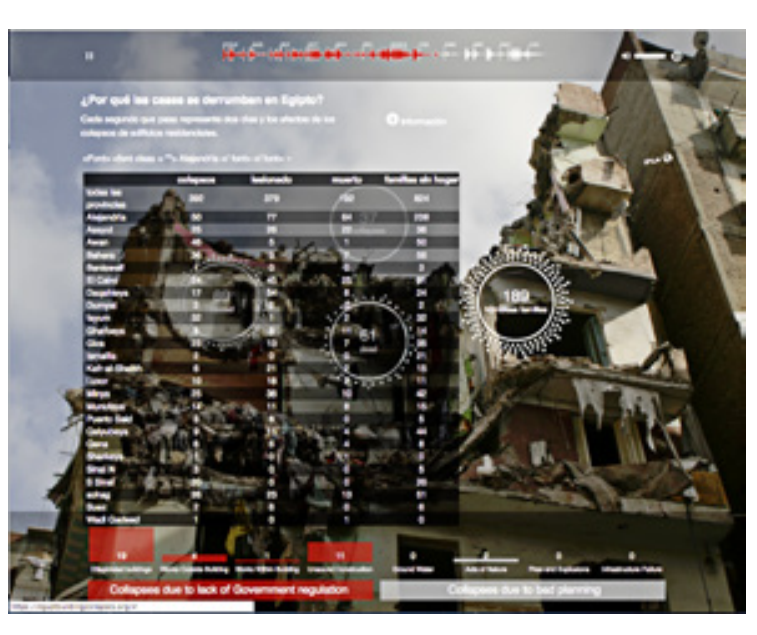

En primera instancia, al plantearse este trabajo Foo pensos a fragmentos de sonidos o música que viniera de los paises de origen de sentimientos de nostalgia por el hogar. Finalmente, se decantó por fragmentos de guitarra y otros sonidos extraídos los que a decir de un antropólogo de ba música, son frecuentemente asociados el hogar.

Malas vibraciones analizadas en este artículo tienden motivo es que estos son menos proclives a molestar o hacer que los oyentes se desconecten, como podría ocurri Esto resuelve un problema, pero

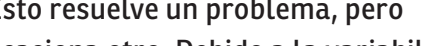
de gustos que presenta la gente y a la incertidumbre respecto a la respuesta emocional que las personas tienen frente a lo que oyen, muchos de los sonidos utilizados en las sonificaciones son usualmente pasivos, insípidos e, incluso, apoliticos. Esto puede obedecer a dos razones centrales. Primero, a la Por estudios, el número de editores nomasculinos de Wikipedia es de apenas 10 por ciento. En consecuencia, crear una sonificación para las ediciones $\mathrm{d}$ Wikipedia equivale tambien a crear el sonido de hombres escribiendo acerca de cultura, historia, cultura populary to Wiatipediay los sonidosuat de Listen

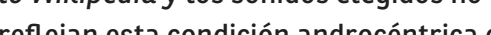
nuestro conocimiento colectivo. Cuando se les preguntó sobre esto, los creador de Listen to Wikipedia dijeron que había desarrollado esta herramienta para que la gente permaneciera escuchando,
para motivar a las personas a dar la para motivar a las personas a dar la bienvenida a los nuevos editores y para reunir a un grupo disperso, pero nopara Un seduclara

Una segunda razon es que cuando temas de género, raza, equad, muerte
At first, for this work Foo looked at using samples of sounds or music coming leaving in order to evoke feelings of nostalgia for home. Finally, he opted for guitar samples and other sounds found in American country music that, said by an anthropologist of music, are sad by loneliness and nostalgia for home.

Bad vibrations

Most of the examples in the collected soundications tend to use more nes bells, clangs and gongs. The reason being that these are less likely to cause offence or based in reality might. This solves one problem but causes another. Due to the variability as to what people tike and the emotional response people have the sonifictions often are passive, unremarkable and even apolitical. This can be understood to be for two central reasons. Firstly, in order not to 'turn off' viewers. For example, according to various studies, there are as little as of Wikipedia. Consequently, to create a sonification of Whipedia edits also culture and science. But the neutrat Look and feel of Listen to Wikipedia and the sounds chosen do not reflect this male-centric writing of our collective knowledge. When asked about this, the creators of Listen to Wikipedia said that they had developed the tool to keep people listening, to encourage bring a dispersed group of people together, rather than to mapt political statement.

A second reason is that when sonifying more complex issues such as gender, sonification producers will use more cause listeners to switch off as sounds 10 per cent non-male identified editors amounts to creating the sound of men

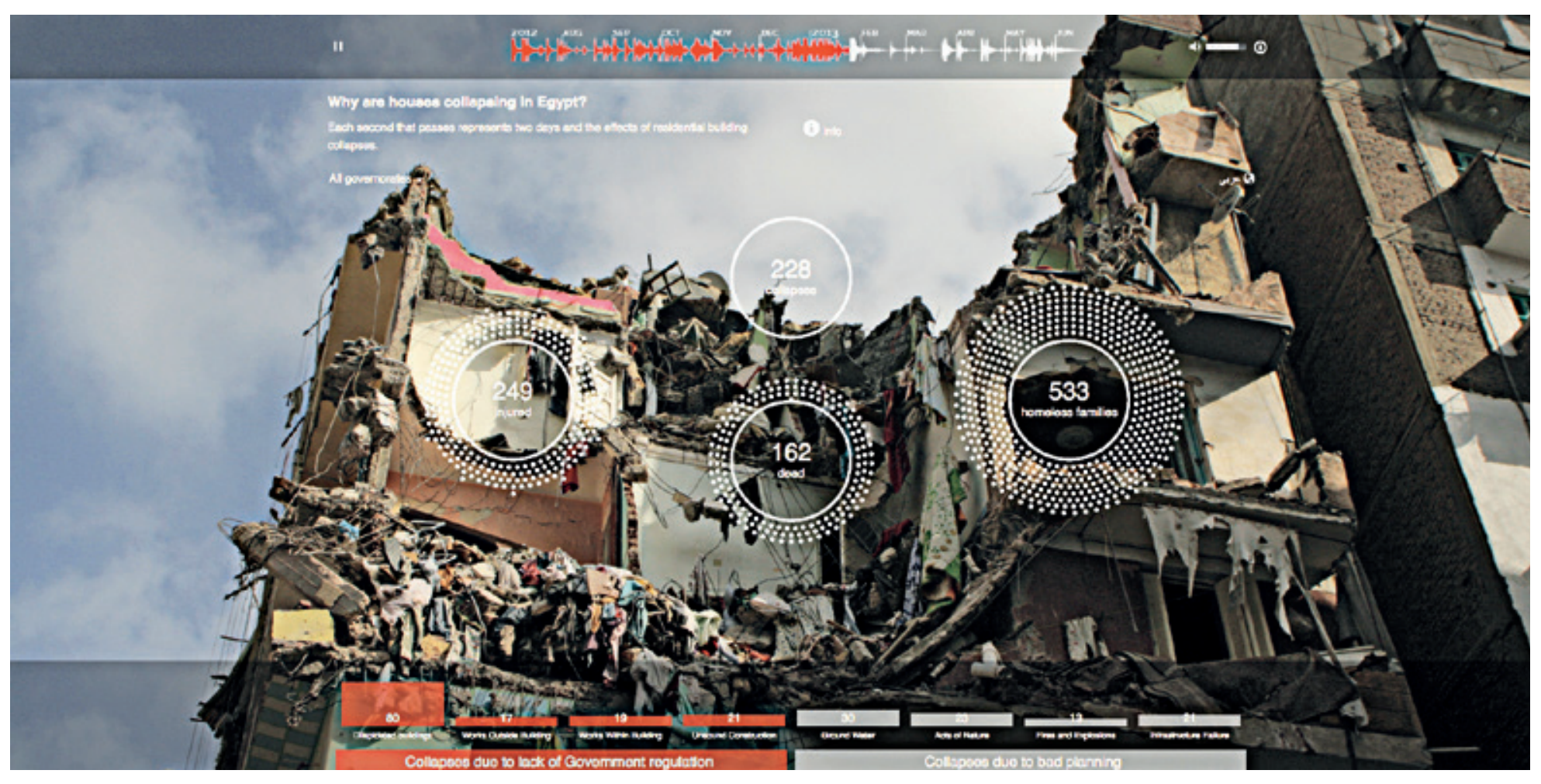

o destrucción, muchos productores de sonificaciones usa lugar de hacer algo que "suene mal. Nosotros enfrentamos este tema cuando diseñamos Egypt Building Collapses, la sonificaciôn del derrum de viviendas en Egipto. Dicho proyecto prioza rese 824 familis sin y 192 víctimas fatales. Eso nos levóa probar dos aproximaciones La primera prueba, más calmada y suave, podría ser descrita como "relajante" o incluso "meditativa". La segunda opción inclu sonidos más realistas de ladrillos cayendo y fundaciones inestables. Est segundo sonido era considerablemente más áspero, a punto que nos preocupaba o se molestara y dejara de escuchar. Finalmente optamos por la segund opción. Cuando le consultamos a Yahi Shawkat, el recolector de la informacion, sobre la elección, nos dijo: «La decisión es correcta. El primer sonido, mas suave y tranquilo, no refleja lo que ocurre. El segundo sonido refleja mejor la situacin. el sonido sea áspero») (comunicación personal, 3 de marzo, 2017).

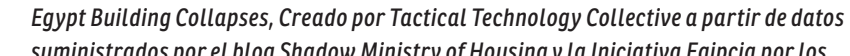
neutral sounds rather than worrying bout 'getting it wrong'.

when designing Gypt Building Collapses. This project had a very serious and sensitive issue to portray with 824 homeless families and 22 casualties. This led us to test out The first was catmer and softeri could be described as 'relaxing' or even 'meditative'. The second test featured mere literal sounds of falling bricks and unstable foundations. This sound was considerably harsher and we worried tha this might cause people to have a viscera reaction or turn off due to the uneasy listening. We finally opted for the second on whether this was the right choice, he said: "I think it was a good choice, the first sound was softer and calmer, which didn't reflect what was going on. The current sound reflects better the situation. I don't think it's a problem with the sound being a harsh sound" (persona

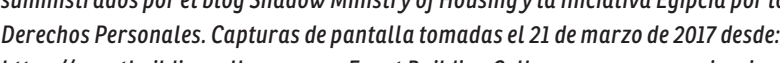

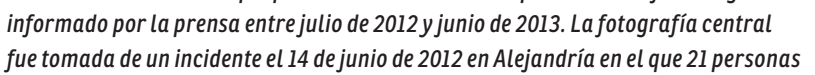

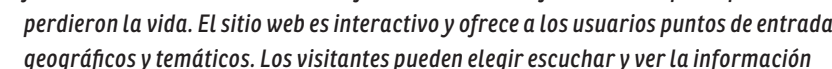
geograficcosy tematiticos. Los visitantes
recolectada en 25 ronas de todo E Eipta

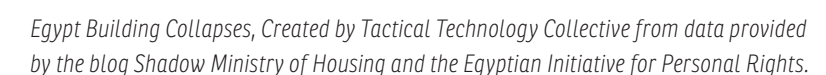

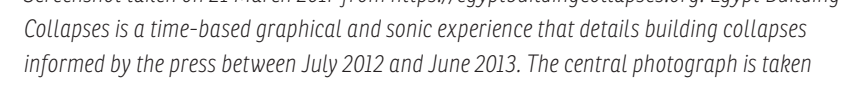

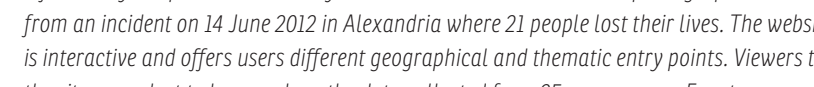

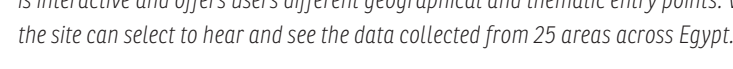
Yahia Shawkat, the coltector of the

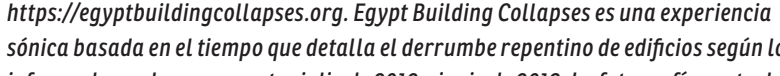

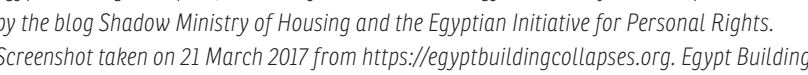


PONIENDO EL SONIDO EN ACCIÓN Además de clasificar los tipos de información que se prestan para la
sonificación, en este artículo nos inter mirar críticamente la idea de que habría pocas sonificaciones debido a que el público de la sonificación se restringe a gente ligada al arte 0 a las ciencias, y que se trataría de un recurso de menor inter
para un público general más amplio.

RUIDO BLANCO

Frecuentemente, las sonificaciones aparecen en nuestros navegadores cuando seguimos algún enlace y muchas veces ni siquiera sabemos de donde provene sonido, fenomeno experiencia "lenta" de la informacion Le preguntamos al mismo Foo, quien ha buscado formas de hacer que las sonificaciones sean accesibles a un público más amplio, si las sonificacio son, a veces, un ruido de fondo que alborota y no hace más que ofrecer un partoteo que distrae del punto en discusión. Esta fue su respuesta:

«Generalmente cuando escucho datos sonificados, lo que usualmen oigo es que suenan como datos. No se saca ventaja de to que la Pienso que esto crea una bar ber. que puede ser más interesante, que puede ser más mainstream. Gente escuchando buena música. El desafio es cómo pueden usarse ciertas características de la música que están relacionadas por el motivo por el cual la gente escuch hace sentirse de cierta manera,
PUTTING SOUND INTO ACTION Besides classifying the types of sonification, in this article we wanted to look critically at the idea that there are few sonifications due to the audience of the sonification being restricted to an a or scientific public, with a lesser interest

WHITE NOISE

Often these sonifications will appear in one's browsers when we click a link and many times we don't even know phenomenon tha Brian Foo describes as a 'slow' data experience, We asked Foo himself, who has been looking at ways of making sonifications more widely accessible if sonifications are, sometimes, a constant background offering meaningless or distracting the issue at hand. This was his answer:

"When I generally hear sonified data, what I usually hear is tha take advantage of what musc and sound does well. I think this creates a barrier, that might be more interesting. That might be more mainstream. People listening to good music, that is interesting, way. The challenge is how you can use the characteristics of music that are related to why people listen to certain music, because It makes them feel a certain way, porque suena bien, porque usa pos de sonidos y composicio interesantes y complejas» febrero de 2017).

CAMUfLAJe de SONIDO

Como en los ejemplos recogidos en este artículo, muchas veces las sonificaciones no son autosoportantes $y$ frecuentemente requieren del apoyo de dres ses dus he entendro sibien los ejemplos aproximación aue privoptan una todos ellos dependen mucho de las visualizaciones. Pero esto no significa necesariamente que una sonificación no pueda ser autosuficiente, sino que, sido encontrado.

Foo combina sus sonidos con videos. Como él explica:

«Es difícil obtener solo con el audio el contexto de algo basado en el sonido. Incluso con los gráficos se necesitan los ejes, se necesita entender qué es lo que estamos mostrando. De es parte del desafío si solo quieres una experiencia sónica. 0 los datos tienen que ser muy simples, y algo a lo que estás acostumbrado, algo que se basa en tiempo o algo más intuitivo. Con algunos de mis trabajos, como Two Trains: Sonification of Income Inequality on the Nrc subway, sin ese contexto, it sounds good, it uses interesting and complex types of sounds and communication, February 27, 2017).

SOUND CAMOUFLAGE were collected, sonifications are often not self-standing, frequently requiring visual depictions to make the information understood. Although all the examples weve analysed took a sound-first backups, Buy this deaniy or visual backups. But this doesn't necessarily alone, but that, up until now, the need axis hasn't yet been found.

Brian Foo combines his sounds with a visual component in the form of videos. As he explains:

"It's hard to get context of something sound based with just the audio. Even with the graph you need the axis, you need to at. So setting up the context is part a sone chatlenge if you just wanted to be very simple, and something that you're used to, something th With some of my work, like Trains: Sonification of Income Inequality on the NYC Subway, without that other context, I don't know if you would get it. I think la sonificación autónoma tiene potencial especialmente con También pienso en el potencial que ofrece el incremento de los podcasts, sobre todo si tienen algo un poco más integrado, donde podría haber una pequeña el contexto antes de presentar música o pieza de sonificación’ (comunicación personal, 27 de febrero de 2017).

UNA CAJA DE HERRAMIENTAS VACiA Los dos productores de sonificaciones entrevistados para este artículo son y y desarrolladores. Esto parece no ser una coincidencia, ya que hay una escasez de herramientas disponibles de fácil uso (plug-and-plap) en hacer sonctiocios, al menos herramientas disponibles para aquellos que desean crear visualizaciones

Brian Foo utiliza las mismas las sonificaciones, pero trabajaría con nuevos géneros o técnicas composicionales. Su tiempo de producción para cada pieza toma entre uno $y$ dos meses. El proceso incluye inestigar la inormación y el tema datos para estructurar la narrativa, recolectar los sonidos y diseñar el algoritmo para reproducir los sonidos. "El gran desconocido", como él lo llama, es cuánto tiempo toma iterar en los sonidos elegidos mientras diseña las reglas. Una vez que presiona play, suena la sonificación. does have potential especially with real time information. Also the rise of podcasts, especilly if they have something a little more integrated where there might be a little bit of takking to get the or the sonification piece" (personat) communication, February 27, 2017).

AN EMPTY TOOLBOX

Both sonification producers interviewed for this article were seems not to be a coincidence, as there is lack of drag and drop, plug and play tools available to create sonifciations compared with the number of tools available to those wanting to create static and interactive visualisations. Brian Foo uses the same tools to

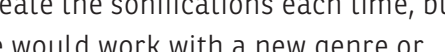
compositional technique His production time for each piece takes between one to two months. The process includes searching the data and the topic, selecting the right dimensions of the data to tell his narrative, collecting algorithm to play the sounds. The 'great unknown', as he refers to it, is how long it takes to iterate on the sounds chosen as he can design the rules, but once he pears how the sonifcation sounds.
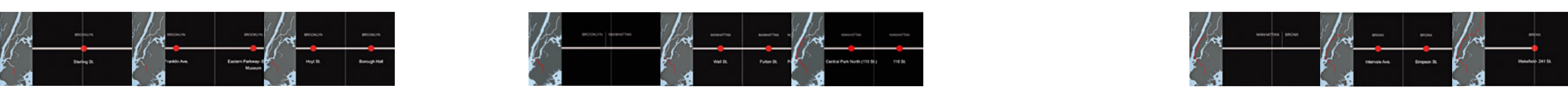

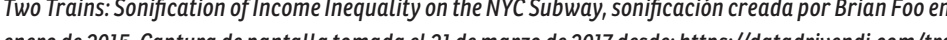

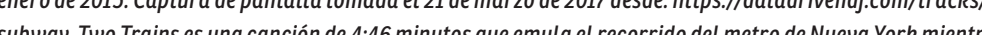
atraviesa Brooklyn, Manhattan yel Bronx L L cantidady ladinamica de losinstrumentos correspondenal

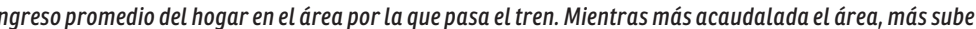


Citica a lo esta no es una contra-

critica a lo visual, sino un argumen

ditivo án por explorar en tode su

vancial Las preguntas planteadas

más allá del medio disponible y

cerca de los métodos utilizados

social: Lo clásico versus aquello aún

por explorar. El punto es no aceptar

por defecto un medio que heredamos,

yue puede estar ya agotado, frente desensibilizados.

No es un hecho desconocido que el

a llegado a un punto de paŕlisis.

retórica en torno al cambio social es

permanentemente señalada por su

redundancia y por no lograr provoca

respuestas. Los temas de justicia/

njusticia se remontan a mucho tiempo

atrás, pero no deben quedar sujetos

las tendencias. El asunto es que

un medio renovado puede generar

ús efpesiente creativa y canal

sonificación está ahí, lista para ser

explorada, para experimentar y jugar

con ella, para conectarse con nuestro

oídos y nuestro entorno. Porque aun

si desconectamos el oír, no podemos

desconectar nuestros oídos; $y$ tal vez

alla afuera, en el vasto mundo deseoso

de ser escuchado, hay personas
During the course of this article we

have introduced various frameworks

benefits and pitfalls

using sonification as a means to

sseminate information. It is importan

creterate that this is not a counter-

an

a

full potential The questions raised

go beyond the medium at hand it

bridges to the necessary discussion

about methods used within political

and social change spheres: the classic

vs. the yet-to-be explored. The point

vs to accept an inherited medium

s the default, and which could be

Itis not a hidden fact that the political 'aralysing standstitt The has reached

requently accused of being redundant and fall short on invoking response. But though issues of justice/injustice trace back in time and shouldn't be subjected to trends. A renewed medium can pose a creative response and a more efficien is there it is rim to bion. Sonification exprimented ris to bexplored, engage our ears and our environment. cannot switch off our ears; and maybe out there, in that vast world eager to be heard, there are people who in return are waiting to listen.

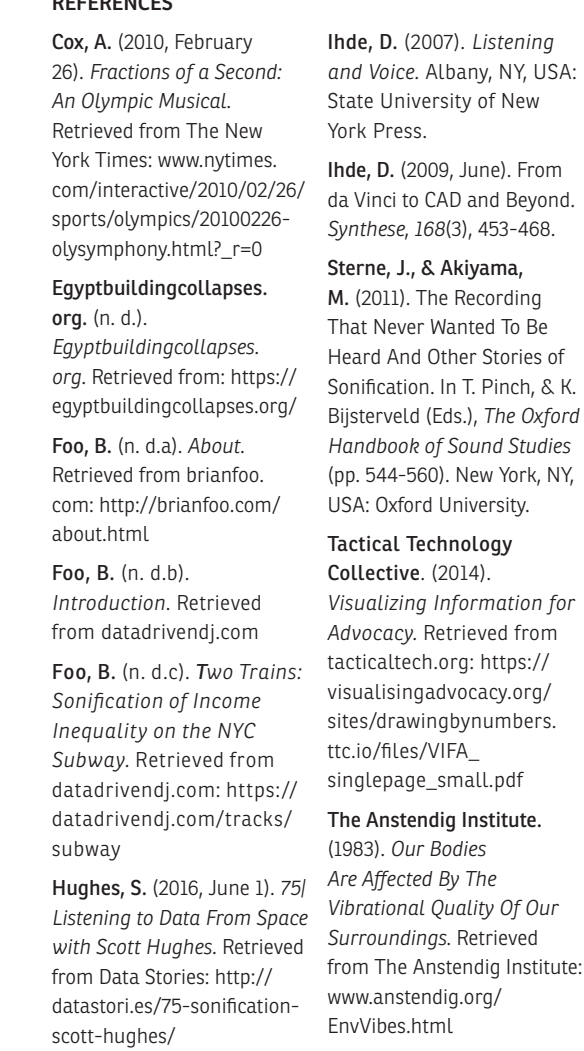

TACTICAL TECH

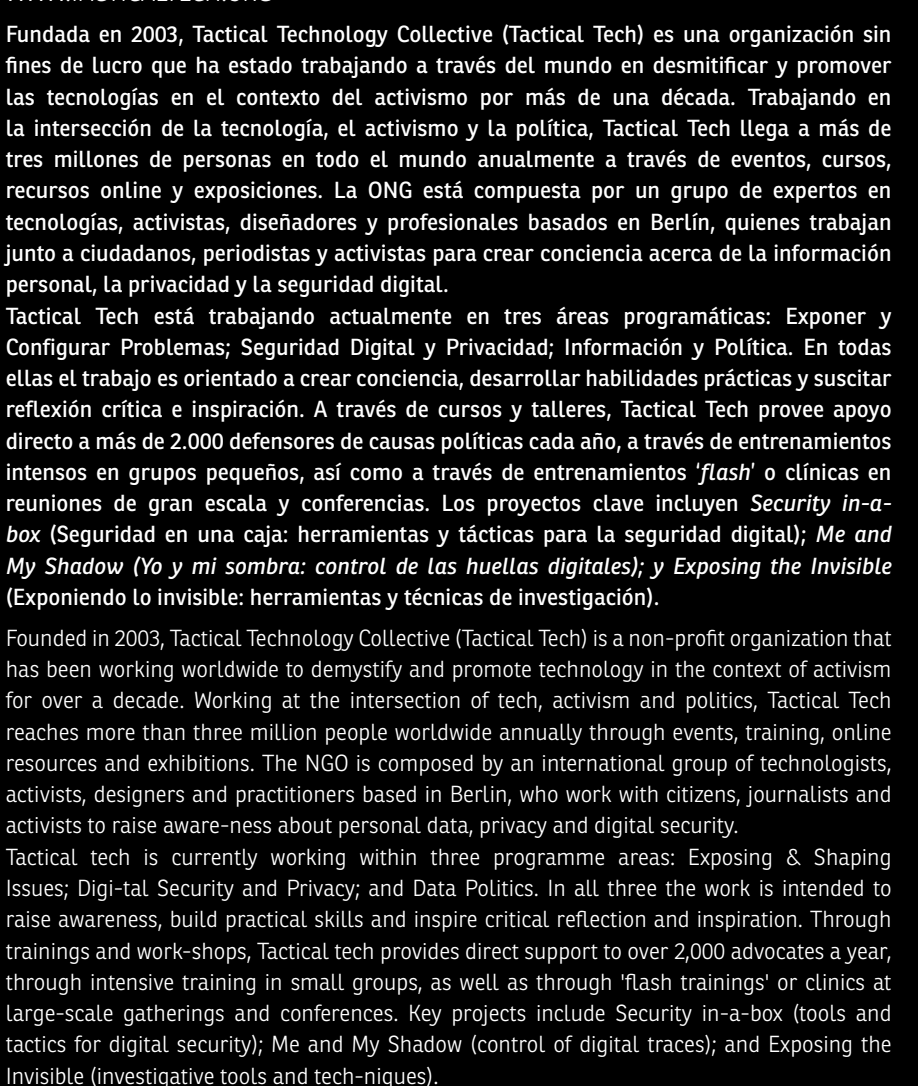

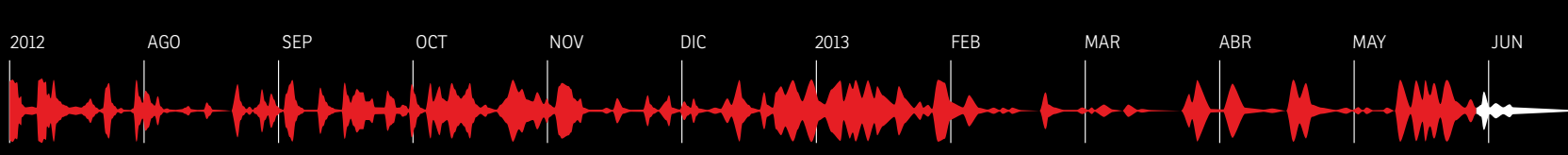

GABI SOBLYYE

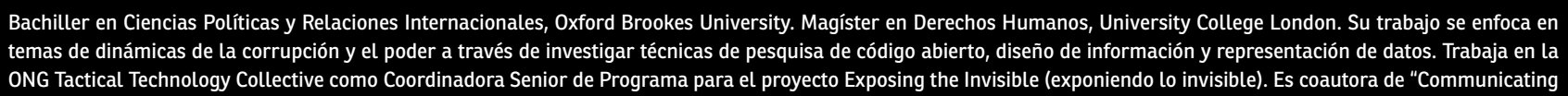

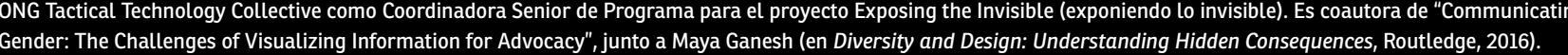

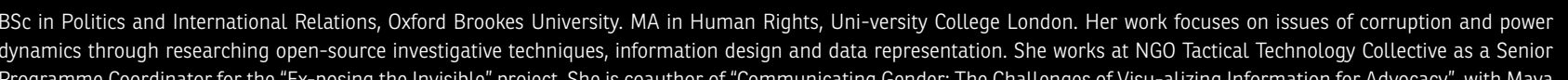

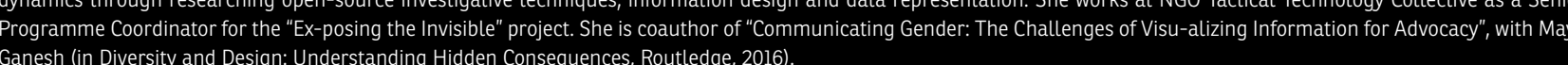

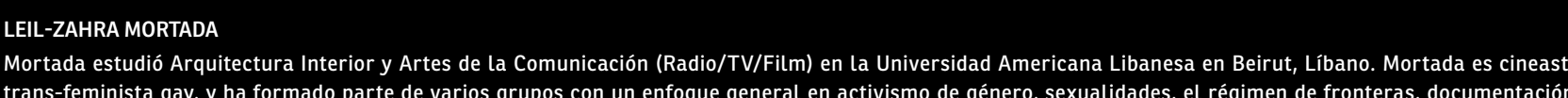

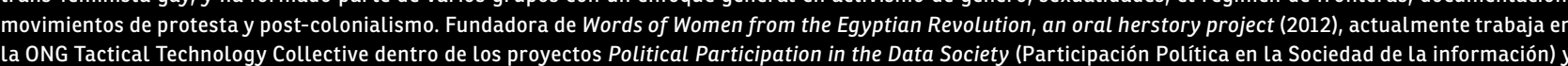

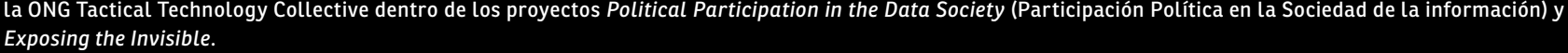

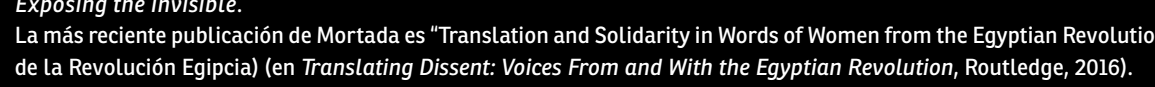

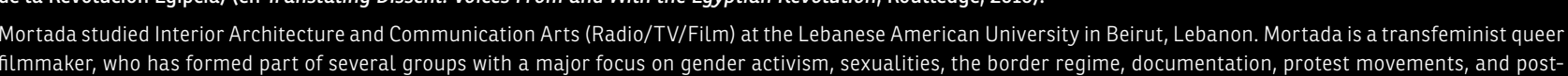

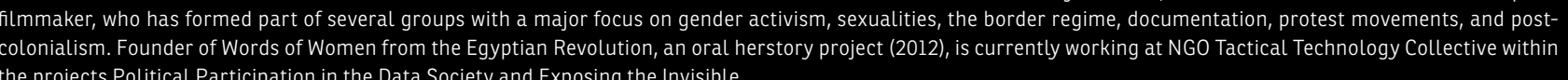

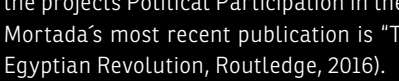

